Special issue:

Marine Heterotrophic Protists

Guest editors: John R. Dolan and David J. S. Montagnes

Review paper

\title{
Living Together in the Plankton: A Survey of Marine Protist Symbioses
}

\section{O. Roger ANDERSON}

Biology, Lamont-Doherty Earth Observatory of Columbia University, Palisades, New York, U.S.A.

\begin{abstract}
Our best evidence is that life arose in the marine environment, and over many millennia of evolutionary proliferation, punctuated by occasional massive extinctions, marine protists have developed remarkably elegant and sometimes complex relationships with prokaryotic and eukaryotic symbionts. Current evidence of the range of marine protist taxa possessing symbionts, including their diversity and physiological functional relationships, is reviewed within an ecological context. Some perspectives are presented on potential opportunities for new avenues of research in unraveling the remarkable adaptive value of two or more genetically diverse marine unicellular organisms living in a close structural and physiological relationship.
\end{abstract}

Key words: Algal symbionts, bacterial symbionts, marine endosymbiosis, microbial physiology, molecular genetics, plankton ecology.

\section{INTRODUCTION}

Current geological evidence indicates that life arose at least 3.5 billion years ago, very likely in deep ocean habitats (e.g. Furnes et al. 2004). During the ensuing millennia, the evolutionary expansion of life in the marine environment produced remarkably diverse organisms, especially among the protists and their microbial co-inhabitants, including bacteria. The complex ecological interactions among these single-celled organisms, including an apparently early adaptation to ingest other smaller organisms as food by phagocytosis, provided a unique physiological circumstance to bring genetically diverse organisms into close intracytoplasmic

Address for correspondence: O. R. Anderson, Biology and Paleo Environment, Lamont-Doherty Earth Observatory, Palisades, New York 10964, U.S.A.; Tel. 845-365-8452; E-mail: ora@LDEO.columbia.edu relationships. Undoubtedly, many endosymbionts (enclosed by host cytoplasm) were engulfed originally in food vacuoles as prey. Subsequently, through a capacity to avoid the normal digestive processes of the predatory host, some of these ingested organisms acquired the capacity to live and reproduce within the affordances of the host intracytoplasmic environment. This inference is based largely on current evidence of induced symbioses in laboratory experiments (e.g. Jeon 1995, Gastrich and Anderson 2002, Kodama and Fujishima 2010) and by earlier theoretical models (e.g. Mereschkowski 1905, Sagan [née Margulis] 1967).

This review of symbiosis in some marine protists focuses especially on plankton, ranging from brackish to open ocean environments. The emphasis is on the diversity and physiological adaptive aspects of protistan endosymbiosis. Three categories of symbiosis are currently recognized: (1) mutualism, where both organisms 
benefit, (2) commensalism, where one species benefits and the other is unaffected, and (3) parasitism, where the host is exploited, sometimes pathologically. Examples of endosymbiosis that are either commensal or mutualistic will be considered based on the best current evidence. Not all published examples can be addressed within the scope and length of this review and other more comprehensive sources are available (e.g. Cavanaugh 1994, Gast et al. 2009, Stoecker et al. 2009). The goal is to pro- vide evidence of some of the diverse ways life has come to evolve in close symbiotic associations among marine planktonic micro-organisms. A survey of symbiotic associations in major host taxonomic groups is presented, followed by a perspective on future potential lines of inquiry. Algal symbioses are commonly observed in oceanic environments (e.g. Fig. 1). However, bacterial and cyanobacterial endosymbioses are also encountered and some examples are included in this review.
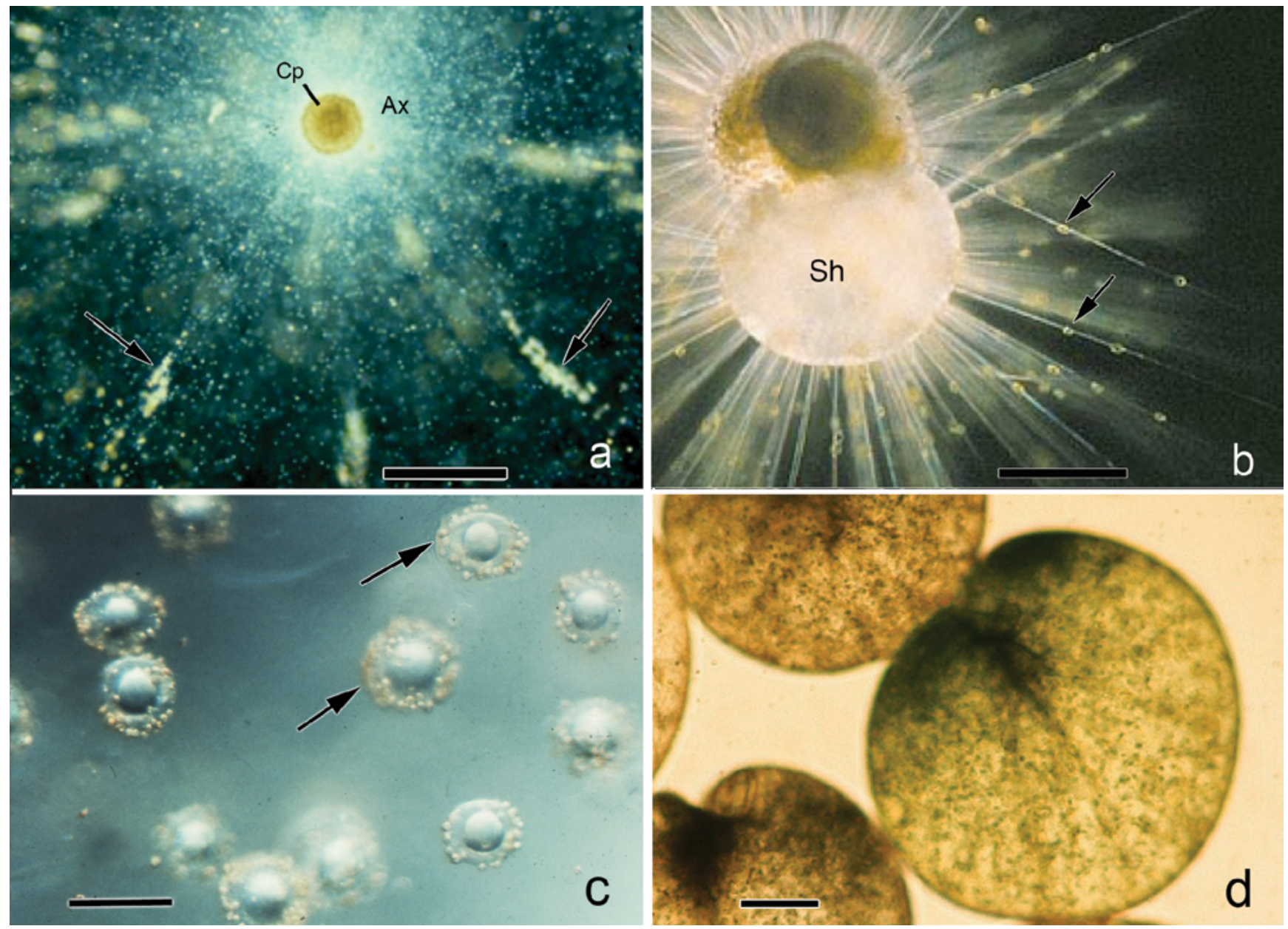

Fig. 1. Light microscopic images of living symbiont-bearing open ocean protists. a - radiolarian showing the central capsule (Cp) containing the nucleus and surrounding cytoplasm, and external to it, long-tapered, radiating pseudopodia known as axopodia (Ax) appearing as a bright halo, including numerous golden-hued algal symbionts on the axopodia (arrows). Scale bar: $500 \mu \mathrm{m} ; \mathbf{b}$ - planktonic foraminiferan bearing a calcitic shell (Sh) and peripherally radiating calcite spines that are covered by pseudopodial cytoplasm bearing scattered algal symbionts (arrows). The small greenish, rounded shell chamber contains dense clusters of symbionts within the intrashell cytoplasm. Scale bar: $100 \mu \mathrm{m} ; \mathbf{c}$ - composite image of a portion of a colonial radiolarian with numerous central capsules containing dinoflagellate symbionts (arrows) in the peripheral cytoplasm of the central capsules. The entire colony is enclosed within a optically clear spherical gelatinous sheath. This portion of the colony is illuminated from the lower right-hand side. Scale bar: $500 \mu \mathrm{m}$; d - the dinoflagellate Noctiluca scintillans (green form) with numerous living prasinomonad algal symbionts (Pedimonas noctilucae), appearing as clumps of green particles, scattered throughout the cytoplasm. Scale bar: $200 \mu \mathrm{m}$. 


\section{SYMBIOSES IN MAJOR TAXONOMIC GROUPS OF MARINE PROTISTS}

\section{Amoebae (naked amoebae, lacking a shell or test)}

Amoebae, in general, are among the least studied members of marine plankton. This may be attributed partially to the sampling techniques typically used. Amoebae are delicate and net sampling often destroys them before they can be isolated. Moreover, amoebae must attach to a surface to feed, thus only particle-rich plankton is likely to support detectable populations of amoebae (e.g. Anderson 2011). Nonetheless, some evidence has accumulated on the presence of endosymbionts in amoebae from diverse open ocean and brackish environments.

A large amoeba (probably Korotnovella sp.) associated with tufts of the planktonic cyanobacterium, Oscillatoria (Trichodesmium) in the Sargasso Sea, contained at least two kinds of intracellular endobacteroids: a larger bacterium enclosed by a double-membrane vacuole and a smaller, electron-dense rod enclosed by a single membrane (Anderson 1977). Their abundance and apparent healthy status as viewed in transmission electron microscopic ultrathin sections suggest they are symbiotic (Fig. 2a). No further evidence is available on the physiological role of the endobacteroids. The molecular phylogenetics of bacterial symbionts in Neoparamoeba aestuarina, isolated from the Ross Sea, Antarctica (Moran et al. 2007), and other Neoparamoeba spp., have been analyzed in relation to host phylogeny by Dyková et al. (2008) who report that phylograms reconstructed from corresponding SSU rDNA sequences of host amoebae and their bacterial symbionts revealed a high level of congruence, indicating strong evidence for coevolution of these two eukaryotic organisms. The bacteria belong to a large group of endobiotic bacteria categorized as Perkinsiella amoebae-like organisms (PLO). To the best of my knowledge, no marine amoeba has been identified with algal endosymbionts. However, at least one freshwater amoeba Mayorella viridis contains zoochlorellae (Page 1988).

\section{Ciliates}

Considerable knowledge has been attained on bacterial symbionts, known as xenosomes, in the marine hymenostome ciliate Parauronema acutum. They are located in the cytoplasm where they grow and divide in close synchrony with the host. When released into cul- ture medium by gentle rupture of the host, the bacteria can infect homologous as well as heterologous Parauronema stocks, including peculiarly a distantly related ciliate, Miamiensis avidus (e.g. Soldo et al. 1992). The xenosomes, while compatible with and stable in a host species are capable of killing other ciliate species. Toxicity, however, varies among the strains of the ciliate xenosomes. The molecular genetics of the xenosomes have been investigated substantially. For example, nonkiller xenosomes contain two plasmids that are similar in length and genetic composition, while killer xenosomes contain four plasmids, two which appear to be genetically similar and two that are distinct. A multicopy genome may help the symbiont survive in the alien environment of the host. Using riboprinting, preliminary results indicated that xenosomes share some degree of homology with two bacterial symbionts, $m u$ and $p i$, found in the freshwater ciliate Pararmecium aurelia. The presence of some homology in the two xenosome genomes may indicate that the marine and freshwater species share a common evolutionary ancestry, or that there has been lateral transfer by some means between freshwater and marine species. The xenosomes, however, share little homology with free-living forms such as E. coli and S. faecalis. This suggests that during early evolution the xenosomes may not have been acquired from ancestors of current free-living forms, or if they were ancestral to modern forms, during the course of subsequent evolution and adaptation in the host, the xenosome genome may have been substantially modified. Limited information is available on the physiology of interactions with the host. However, Soldo et al. (1992) reported that the oxygen consumption rate of xenosome-bearing hosts is 20 to $30 \%$ higher than that of xenosome-free hosts. Moreover, host glycogen is consumed at a significantly higher rate in xenosomebearing $P$. acutum compared to those without the symbionts. Remarkably, $30 \%$ of the symbiont protein molecules were derived from the host, indicating a complex metabolic relationship.

Methanogenic (methane-producing) disc-shaped, symbiotic bacteria have been identified in the marine ciliate Plagiopyla frontata (Fenchel and Finlay 1991). The bacteria are arranged in close contiguity with hydrogenosomes, organized in alternating layers resembling stacks of coins. The timing of symbiont reproduction is controlled by the host-cell cycle. The bacteria remain constant at about 3,500 per cell during the growth phase. The host is known to obtain an ener- 

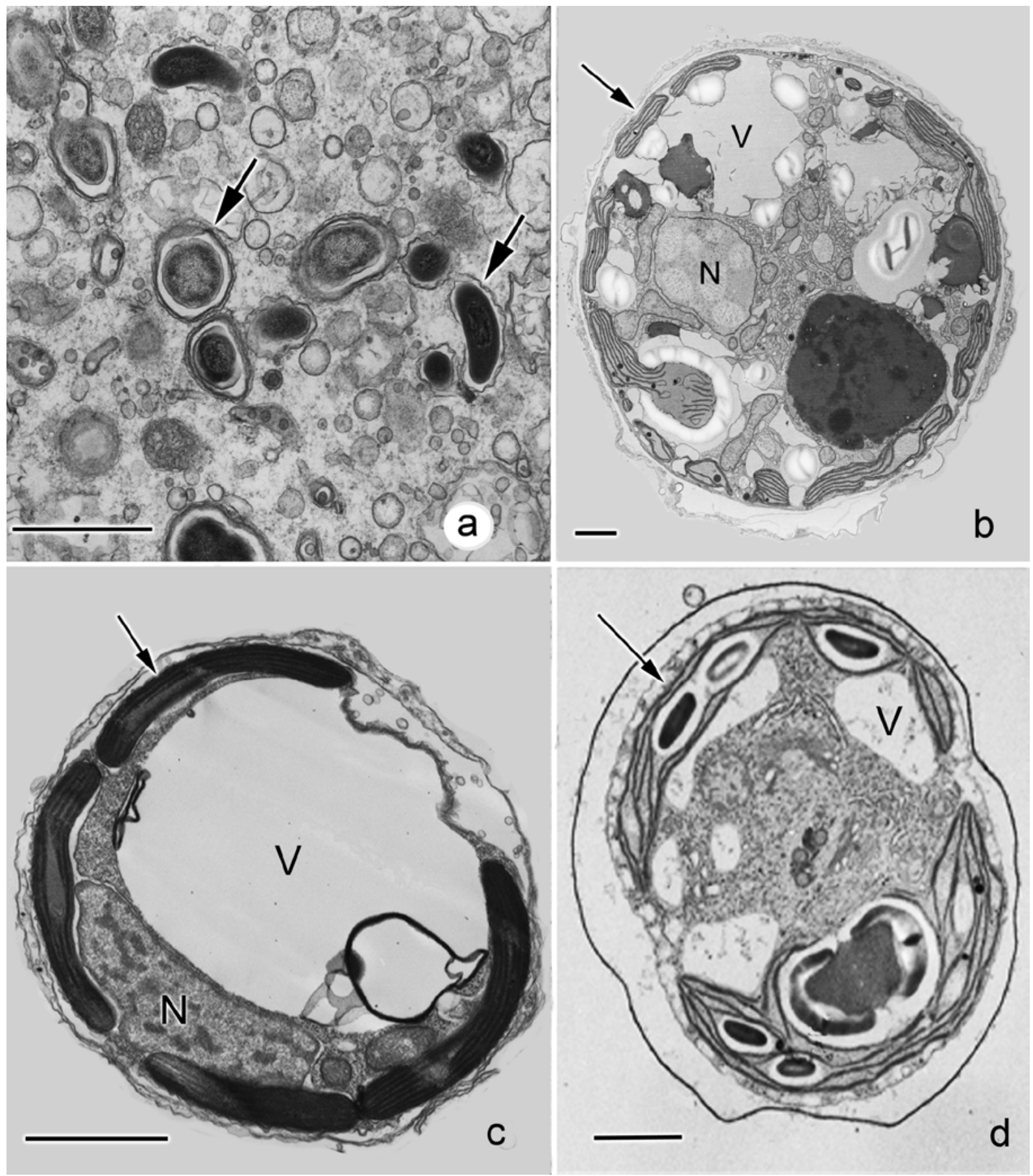

Fig. 2. Transmission electron microscopic ultrathin section images of symbionts in some open ocean protists. $\mathbf{a}$ - free-living open ocean amoeba with two kinds of intracytoplasmic bacteroids (arrows): round to oval within double membranes, and curved dense rod within a single-membrane vacuole; $\mathbf{b}$ - dinoflagellate symbionts as found in planktonic foraminiferans and radiolarians; $\mathbf{c}$ - putative prymnesiid symbiont from a radiolarian; $\mathbf{d}$ - prasinomonad symbiont from a large spongiose skeletal radiolarian. Figs. b-d: $\mathrm{N}$ - nucleus, V - vacuole, arrows - light absorbing plastids (adapted from Anderson 1983). All scale bars: $2 \mu \mathrm{m}$. 
getic advantage from the bacterial symbionts (Fenchel and Finlay 1991). This may confer survival advantage where exogenous sources of energy are limited.

Cyanobacterial symbionts as well as marine proteobacteria have been documented by transmission electron microscopy in an open ocean tintinnid, $\mathrm{Co}$ donella sp. (e.g. Foster et al. 2006). The cyanobacteria had three to four thylakoids throughout the cytoplasm, glycogen in packets scattered between thylakoids, and carboxysomes in central clusters. Putative cyanobacterial-like endosymbionts also have been documented in an unusual cercozoan tetraflagellate (Auranticordis quadriverberis) isolated from marine interstitial sand samples (Chantangsi et al. 2008).

Algal symbioses are less common in marine ciliates compared to freshwater ciliates. However, kleptoplasty (the capture of functional and relatively long lasting plastids from ingested prey) is more widely documented in marine ciliates (e.g. Haberlandt 2012, Lindholm and Mork 1989, Stoecker et al. 2009), thus reducing their dependence entirely on autotrophic prey as a source of carbon nutrition. The presence of cytoplasmic plastids in oligotrich ciliates, among the most abundant protists in the sea, provides additional sources of nutrition in addition to heterotrophic modes of nutrition. Moreover, as grazers on primary producers and prey for metazoan plankton, they constitute an important source of mixotrophic fixation of carbon (e.g. Stoecker et al. 1988), thus augmenting their more general role as a link in ocean planktonic food webs (e.g. Dolan et al. 2002, Montagnes et al. 1988, Ota and Taniguchi 2003, Perez et al. 1997).

In some cases, kleptoplasty can provide carbon nutritional resources at higher concentrations in the host than in the original algal prey where the plastids were captured. Among the more detailed studies to document the adaptive value of kleptoplasty for the host, McManus et al. (2012) examined the advantages and costs of sequestering plastids by Strombidium rassoulzadegani, a planktonic mixotrophic ciliate that obtains a nutritional subsidy by photosynthesis. They reported that the ciliate contained 60 times the carbon content of its algal prey, but more than 100 times the chlorophyll content. However, C-14 tracer studies showed that inorganic carbon uptake in the light (expressed per unit chlorophyll) was about half that of the algal prey. Due to the higher chlorophyll content in the ciliate, however, the $\mathrm{C}$ turnover in ciliate and alga was about equal ( 0.13 and $0.14 \mathrm{~d}^{-1}$, respectively). Growth increased ap- proximately as a hyperbolic function with increasing light intensity from zero to $200 \mu \mathrm{mol}$ photons $\mathrm{m}^{-2} \mathrm{~s}^{-1}$, reaching a maximum at $50 \mu \mathrm{mol} \mathrm{m} \mathrm{m}^{-2} \mathrm{~s}^{-1}$. Plastid-containing ciliates were positively phototactic. The ciliate showed excellent growth with Rhodomonas lens and Tetraselmis chui as prey. Growth in the light was substantially greater than in the dark with both sources of food, but varied with other food sources.

Additional evidence of the role of sequestered plastids, in this case from cryptomonads, in Myrionecta rubra (= Mesodinium rubrum), a ciliate that is globally distributed in neritic and estuarine habitats, showed that light-saturated rates of photosynthesis for individual ciliates ranged from 13 to $88 \mathrm{pg} \mathrm{C}$ cell $^{-1} \mathrm{~h}^{-1}$, a rate that was within the mid-range reported for community measurements made during Mesodinium blooms in redwaters and within the range reported for phytoplankton (Stoecker et al. 1991). Furthermore, Johnson et al. (2006) report that Myrionecta rubra maintained chlorophyll per cell and maximum cellular photosynthetic rates that were 6-8 times that of the prey alga, Geminigera cf. cryophila. However, while maximum chl-specific photosynthetic rates were identical between the host and alga, M. rubra was less efficient at light harvesting in low light (10 and $25 \mu \mathrm{mol}$ photons $\left.\mathrm{m}^{-2} \mathrm{~s}^{-1}\right)$ and had lower overall quantum efficiency. With respect to metabolic nutritional efficiency, $G$. cf. cryophila possessed a greater capacity for synthesizing protein from photosynthate, while M. rubra used 3.2 times more fixed $\mathrm{C}$ for synthesizing lipids. As with other kleptoplastidic ciliates, the plastids (though not permanently genetically integrated) undergo replication and the number are regulated by $M$. rubra, allowing the ciliate to function as a phototroph.

\section{Dinoflagellates}

Dinoflagellates, commonly symbionts within other protists as reviewed below, also harbor bacterial or algal endosymbionts. Heterotrophic dinoflagellates (e.g. Ornithocercus, Histioneis and Citharistes) in the Gulf of Aqaba, Red Sea (ranging from 3 to 6 cells $1^{-1}$ ), were found to contain cyanobacterial symbionts within intracellular "phaeosomes," formed by unicellular cyanobacteria of the Synechococcus or Synechocystis types (Gordon et al. 1994). The peak occurrence of the symbiont-bearing dinoflagellates correlates with the onset of nitrogen limitation in late summer and autumn due to extreme thermal stratification. The sequestration of the cyanobacteria within the phaeosome may provide the necessary anaerobic environment to support $\mathrm{N}$ fixa- 
tion by the cyanobacterial symbionts in the oligotrophic water. The authors propose that the cyanobacterial association may be mutually advantageous to host and symbiont, because the cyanobacteria may exude a large proportion of their fixed carbon to the host, thus increasing host metabolism and accelerating oxygen consumption in their immediate proximity and activating the $\mathrm{N}$-fixing nitrogenase for a longer time than their free-living peers.

Cyanobacterial associations of Richelia intracellularis within diatoms in this locale have also been reported (e.g. Kimor et al. 1992) and may confer a similar physiological mutual advantage as the dinoflagellate/ cyanobacterial symbioses in these oligotrophic waters.

Foster et al. (2006) confirmed the presence of cyanobacteria in Histioneis sp. and one other open ocean dinoflagellate Ornithocercus sp. collected along cruise transects between $622-972 \mathrm{~km}$ northwest of Hawaii in the Pacific Ocean.

The large, bloom-forming dinoflagellates Noctiluca scintillans (= Noctiluca miliaris) harbors endocytic bacteria, forming a turbid mass within a small fraction of a population (typically $\sim 1 \%$ in some locales). The diversity of the endocytic bacteria was investigated by denaturing gradient gel electrophoresis (DGGE) and compared to that of free living bacteria in the surrounding environment (Seibold et al. 2001). The DGGE analysis showed that the consortium of endocytic bacteria was distinctly different from the free-living marine bacteria. Moreover, among other findings from molecular genetic analyses, 16 bacterial isolates taken from single Noctiluca cells, characterized by $16 \mathrm{~S}$ rRNA phylogenetic analyses, showed that most (14 strains) belonged to several groups of the $\gamma$ subdivisions of Proteobacteria, two isolates were related to the Vibrio group and one isolate to Moraxella. The ecological and physiological significance of these diverse and abundant endosymbionts is not known; although, laboratory experiments indicate that the bacteria may influence the growth of Noctiluca (Kirchner et al. 1999).

Bacterial endobionts in the cytoplasm and nucleoplasm of Gyrodinium instriatum, an athecate photosynthetic dinoflagellate, often abundant in seawater and coastal lagoons along the Portuguese coast, have been confirmed by transmission electron microscopy and confocal TSA-FISH analyses (Alverca et al. 2002). All endonuclear and most of the endocytoplasmic bacteria labeled were identified as belonging to the betaproteobacteria; whereas, large clusters of CytophagaFlavobacterium-Bacteroides (CFB) were labeled and observed in the cytoplasm of the dinoflagellate cells, but were absent from the nucleus. CFB associated with the cytoplasm appeared to reflect a degradation process occurring in moribund dinoflagellate cells, but the systematic colonization of dinoflagellate nucleoplasm by betaproteobacteria suggested a true symbiotic relationship.

Noctiluca scintillans also harbors a green prasinophyte algal symbiont (Pedimonas noctilucae), confirmed by transmission electron microscopy (Sweeney 1978). This dinoflagellate occurs as two forms, the green symbiont-bearing form (e.g. Fig. 1d) and a colorless one lacking the symbiont. The green form produced large blooms $\left(3 \times 10^{6}\right.$ cells $\left.1^{-1}\right)$ in the northern Arabian Sea during the 2000 spring intermonsoon bloom, covering a vast area between 17-21 degrees $\mathrm{N}$ and 66-70 degrees E (Madhu et al. 2012), confirming earlier reports of similar blooms in the northeast Monsoon and the Spring Intermonsoon (Gomes et al. 2008). The presence of the symbiont in these naturally occurring $N$. scintillans populations may contribute to their explosive growth, making the northeastern Arabian Sea highly productive (mean $607 \pm 338 \mathrm{mg} \mathrm{C} \mathrm{m}^{-2}$ $\mathrm{d}^{-1}$ ) even during oligotrophic periods such as the spring intermonsoon. However, in prior studies of the colorless and symbiont-bearing N. scintillans from the Seto Inland Sea, Japan by Furuya et al. (2006), no differences were found in growth rate between the colorless heterotrophic $N$. scintillans $\left(0.28 \mathrm{~d}^{-1}\right)$ and the symbiontcontaining individuals $\left(0.33 \mathrm{~d}^{-1}\right)$. The culture conditions were likely more favorable for phagotrophy than in the Arabian Sea. The authors conclude that phagotrophy promotes faster growth, but symbiosis may support survival under food limitations. The ecological significance of green $N$. scintillans was examined by Hansen et al. (2004) who reported the photosynthesis rate and relative effects of illumination and phagotrophy on growth in laboratory cultures. Photosynthesis of cells collected from the field, without added prey, increased with irradiance to $\sim 200 \mathrm{ng} \mathrm{C}$ cell ${ }^{-1} \mathrm{~d}^{-1}$ at an irradiance of $\sim 250$ to $300 \mu \mathrm{mol}$ photons $\mathrm{m}^{-2} \mathrm{~s}^{-1}$. When supplied with prey, growth rates were $0.09-0.24 \mathrm{~d}^{-1}$ at irradiances of 45 and $150 \mu \mathrm{mol}$ photons $\mathrm{m}^{-2} \mathrm{~s}^{-1}$ and prey concentrations of 1,610 and 2,740 $\mu \mathrm{g} \mathrm{C}^{-1}$, respectively; much higher than the growth rates without prey $\left(0.058\right.$ and $0.14 \mathrm{~d}^{-1}$ at irradiances of 45 and $150 \mu \mathrm{mol}$ photons $\mathrm{m}^{-2} \mathrm{~s}^{-1}$ ). A comparison of the contribution of photosynthesis and phagotrophic nutrition to the carbon metabolism showed that phagotrophy only contributed significantly to the direct growth of the green $N$. scintil- 
lans at an irradiance of $150 \mu \mathrm{mol}$ photons $\mathrm{m}^{-2} \mathrm{~s}^{-1}$, when prey concentration was very high.

\section{Planktonic foraminiferans}

Because of their significant role in carbonate biomineralization in the open ocean and the importance of their calcite shells in ocean sediments as micropaleontological evidence, planktonic foraminiferans have received considerable ecological research attention, including the role of their algal symbionts. The most common algal symbionts associated with planktonic foraminiferans are dinoflagellates (Fig. 1b) (e.g. Anderson and Bé 1976, Anderson and Lee 1991, Gast and Caron 2001), although other algal groups (e.g. chrysomonads) are also present in some non-spinose species (Hemleben et al. 1989). At daybreak, the symbionts (contained within membrane-bound vacuoles) are moved from the intrashell cytoplasm onto the surface of the spines and peripheral pseudopodial network by host cytoplasmic streaming, forming a spectacular array of yellow-green symbionts distributed among the spines. At evening, the symbionts are withdrawn into the shell, apparently as a form of protection. Although no evidence has been gathered to show that the symbionts of planktonic foraminifera directly provide food to the host, there is indirect evidence. Shell growth is more robust when illuminated. But in prolonged absence of illumination, shell growth stops and the foraminiferan undergoes reproduction, releasing numerous flagellated swarmers (e.g. Hemleben et al. 1989). The swarmers lack symbionts, and apparently must acquire them from the surrounding environment at each new generation.

\section{Radiolarians and acantharians}

Radiolarians are largely open ocean silica-secreting protists producing remarkably elegant glassy silicate skeletons of varied geometric forms. They occur as solitary (Fig. 1a) and colonial (Fig. 1c) species; the latter with numerous individual radiolarian cells interconnected by cytoplasmic strands and enclosed by a clear gelatinous sheath, varying in shape from spheroidal to elongated and tube like, sometimes segmented. Acantharians, considered close relatives of radiolarians, produce typically spinose skeletons composed of strontium sulfate (celestite). Algal symbionts in acantharians include dinoflagellates and prymnesiida (e.g. Febvre and Febvre-Chevalier 1979). Moreover, there is evidence that Phaeocystis spp. are common associates of acantharians, globally; and that symbiont biogeography, rather than host taxonomy, is the main determinant of the association (Decelle et al. 2012). The symbionts of radiolarians include dinoflagellates (Fig. 2b), brownpigmented cells, probably prymnesiida (Fig. 2c), and prasinomonads (Fig. 2d) (e.g. Anderson 1983, 1990; Gast and Caron 2001). In some cases endocytoplasmic bacteroids occur within some spongiose skeletal species (Anderson and Matsuoka 1992). The bacteroids have been identified as cyanobacteria in Dictyocoryne truncatum and Spongostaurus sp. (Foster et al. 2006). Furthermore, Yuasa et al. (2012) using morphologic and molecular evidence have reported the presence of cyanobacterial symbionts in Dictyocoryne profunda.

There is good C-14 tracer evidence that the eukaryotic algal symbionts provide photosynthetic-derived carbon compounds for host nutrition (e.g. Anderson 1978; Anderson et al. 1983). The amount of C-14 labeled carbon contributed to the radiolarian central capsule by the symbionts in an illuminated culture (3-4 h) for a solitary species (Thalassicolla nucleata) and a colonial species (Collosphaera huxleyi) ranged from $0.73 \times 10^{-2}$ to $2.55 \times 10^{-2} \mu \mathrm{g}$ for T. nucleata and $\sim 14 \times 10^{-7} \mu \mathrm{g}$ for $C$. huxleyi (the latter has much smaller central capsules). The amount of C-14 labeled $\mathrm{C}$ was positively correlated with the photosynthetic productivity of the host symbionts. Among the C-14 labeled organic compounds in the central capsules, carbohydrates, lipid and proteins were detected. In most species of radiolarians, the algal symbionts are distributed peripherally in the array of cytoplasmic axopodia or pseudopodial network during the day, and withdrawn close to the central capsule as evening approaches, similar to the diel process in planktonic foraminiferans. Radiolarians reproduce by release of flagellated swarmers, devoid of symbionts, and each generation of radiolarians must acquire a new supply of symbionts from the natural environment.

Although radiolarians and planktonic foraminiferans are not considered to be major members of the open ocean plankton, based on their relatively sparse abundances, the photosynthesis of their symbionts can be substantially more than that of primary producers in a similar volume of water in the surrounding open ocean, particularly in oligotrophic regions such as the Sargasso Sea (Caron et al. 1995). Solitary and colonial radiolarians had the highest primary production rates among the sarcodines studied, including Acantharia. The total symbiont production contributed a small fraction (generally $<1 \%$ ) of the total primary production in surface waters. However, by combining the production rates measured in the study with seasonal abundances 
of all of the symbiont-bearing sarcodines, these assemblages may have contributed an average of $\sim 5 \%$ to total annual primary production (Caron et al. 1995).

\section{SOME PERSPECTIVES ON FUTURE RESEARCH}

The evolution of a close, intracytoplasmic relationships between two or more species of diverse genetic origin as occurs in endosymbiotic associations is an intriguing topic from an intellectual perspective in addition to its theoretical scientific importance. During evolution, there is good evidence that organisms tended to develop adaptive strategies to prevent invasion by other organisms, including various immunological defense mechanisms and other means of preventing invasion through protective surface structures. A phagotrophic style of nutrition, that apparently developed early in the origin of single-celled eukaryotes, provides an efficient means of capturing food; but it also opens the predator's cytoplasm to invasion by ingested organisms that develop adaptive strategies to exploit the host's intracellular environment. This can lead to parasitism in the most exploitative adaptation, or a more supportive adaptive association as in mutualism and commensalism. In view of this adaptive dilemma, further research may elucidate what properties of the symbiont and host are most significant in determining which kind of association is formed.

Open ocean organisms have become adapted to widely diverse habitats varying in physical, chemical, and nutritional value. The open ocean in some locations is highly oligotrophic, and among other locales is the site of some of the most dramatic forms of hostsymbiotic associations, some of them reviewed here. Although we are making substantial progress in understanding how a relatively permanent association occurs between a host and its endosymbionts, cytologically (Kodama and Fujishima 2009, Reisser 1992) and in terms of ecological factors (e.g. Nakajima et al. 2009, Strom 2008), much remains to be done in deciphering the molecular and physiological mechanisms involved. The use of modern molecular genetic methods to probe the genetic mechanisms for a relatively permanent endocytoplasmic association between two or more alien species is most promising, including the genetic basis for avoiding predation of the incipient symbiont by the host. This may include mRNA evidence of gene activa- tion during the development of symbiotic associations in experimental conditions (e.g. Jeon 1995, Nakajima et al. 2009), or during the varied activities that occur in normal cell cycles by host and symbiont. For example, what are the control mechanisms to ensure that there is a relatively stable number of symbionts during host vegetative and reproductive stages? In those species where the host loses its symbionts during reproduction and must access them in the next generation, environmental sampling and qPCR may help to determine the distribution and quantity of symbionts in the host environment available for reinfection. One of the more interesting, yet challenging, research questions is how the temporal cycles of activity and metabolic responses of host and symbiont (e.g. the diel changes in distribution of algal symbionts within the cytoplasm of some oceanic sarcodines, and transfer of photosynthates to host) are regulated. Modern molecular genetics coupled with additional more refined C-14 tracer studies, and biochemical enzyme assays in short- and long-term time series studies, may help to elucidate these phenomena.

It is also important to understand the origin and development of different forms of endocytic symbiotic associations, e.g. when the symbiont is enclosed within a membranous vacuole versus where the symbiont is freely suspended in the cytoplasm. What are the genomic differences between these two types of symbioses, and what differences if any are characteristic of algal versus bacterial endosymbioses of these two types? We have relatively limited evidence of the nutritional interactions of symbiont and host in open ocean planktonic symbiotic organisms, and much more fundamental ecophysiological research is needed to unravel the nutritional and metabolic pathways involved, including how much of the host energy and material demands are met by the symbionts, and what affordances are provided by the host. Is an oligotrophic environment more likely to produce endosymbiotic associations, or have organisms with the capacity to develop endosymbioses invaded and exploited these environments? Given the importance of understanding the diversity of life within marine planktonic ecosystems, and the flow of energy and matter among the constituent species, a more thorough understanding of marine symbioses is likely to open new insights into the dynamics of how marine planktonic communities have evolved over geological time spans and have become one of the most elegant and significant components of our global biogeochemical environment. 
Acknowledgements. I thank Drs. Joaquim Goes and Helga Gomes for contributing the image of Noctiluca scintillans. This is LamontDoherty Earth Observatory contribution number 7655.

\section{REFERENCES}

Alverca E., Biegala I. C., Kennaway G. M., Lewis J., Franca S. (2002) In situ identification and localization of bacteria associated with Gyrodinium instriatum (Gymnodiniales, Dinophyceae) by electron and confocal microscopy. Eur. J. Phycol. 37: $523-530$

Anderson O. R. (1977) Fine structure of a marine amoeba associated with a blue-green alga in the Sargasso Sea. J. Protozool. 24: $370-376$

Anderson O. R. (1983) Radiolaria. Springer Verlag, N. Y., p. 119

Anderson O. R. (1978) Fine structure of a symbiont-bearing colonial radiolarian Collosphaera globularis and 14C-isotopic evidence for assimilation of organic substances from its zooxanthellae. J. Ultrastruc. Res. 62: 181-189

Anderson O. R. (1990) Radiolarian Algal Symbioses. In: Algae and Symbioses, (Ed. W. Reisser). Bristol, BioPress, Ltd., pp. 93-109

Anderson O. R. (2011) Particle-associated planktonic naked amoebae in the Hudson Estuary: Size-fraction related densities, cell sizes and estimated carbon content. Acta Protozool. 50: 15-22

Anderson O. R., Bé A. (1976) The ultrastructure of a planktonic foraminifer, Globigerinoides sacculifer (Brady) and its symbiotic dinoflagellates. J. Foraminiferal Res. 6: 1-21

Anderson O. R., Lee J. J. (1991) Foraminiferan Cytology and Fine Structure. In: Foraminifera, (Eds. J. J. Lee and O. R. Anderson). Academic Press, London, pp. 7-40

Anderson O. R., Matsuoka A. (1992) Endocytoplasmic microalgae and bacteroids within the central capsule of the radiolarian Dictyocoryne truncatum. Symbiosis 12: 237-247

Anderson O. R., Swanberg N. R., Bennett P. (1983) Assimilation of symbiont-derived photosynthates in some solitary and colonial radiolaria. Mar. Biol. 77: 265-269

Caron D. A., Michaels A. F., Swanberg N. R., Howes F. A. (1995) Primary productivity by symbiont-bearing planktonic sarcodines (Acantharia, Radiolaria, Foraminifera) in surface waters near Bermuda. J. Plankton Res. 17: 103-129

Cavanaugh C. M. (1994) Microbial symbiosis: Patterns of diversity in the marine environment. Amer. Zool. 34: 79-89

Chantangsi C., Esson H. J., Leander, B. S. (2008) Morphology and molecular phylogeny of a marine interstitial tetraflagellate with putative endosymbionts: Auranticordis quadriverberis n. gen. et sp. (Cercozoa). BMC Microbiol. 8: 123, doi:10.1186/14712180-8-123

Decelle J., Probert I., Bittner L., Desdevises Y., Colin S., de Vargas C., Gali M., Simó R., Not F. (2012) An original mode of symbiosis in open ocean plankton. Proc. Natl. Acad. Sci. U.S.A. 109: $18000-18005$

Dolan J. R., Claustre H., Carlotti F., Plounevez S., Moutin T. (2002) Microzooplankton diversity: relationships of tintinnid ciliates with resources, competitors and predators from the Atlantic Coast of Morocco to the Eastern Mediterranean. Deep Sea Res. Part I Oceanogr. Res. Pap. 49: 1217-1232

Dyková I., Fiala I., Pecková H. (2008) Neoparamoeba spp. and their eukaryotic endosymbionts similar to Perkinsela amoebae (Hollande, 1980): Coevolution demonstrated by SSU rRNA gene phylogenies. Europ. J. Protistol. 44: 269-277
Febvre, J., Febvre-Chevalier C. (1979) Ultrastructural study of zooxanthellae of three species of Acantharia (Protozoa: Actinopoda) with details of their taxonomic position in the Prymnesiales (Prymnesiophyceae, Hibberd, 1976). J. Mar. Biol. Assoc. (U.K.) 59: $215-226$

Fenchel T., Finlay B. J. (1991) Synchronous division of an endosymbiotic methanogenic bacterium in the anaerobic ciliate Plagiopyla frontata Kahl. J. Protozool. 38: 22-28

Foster R., Carpenter E. J., Bergman B. (2006) Unicellular cyanobionts in open ocean dinoflagellates, radiolarians, and tintinnids: Ultrastructural characterization and immuno-localization of phycoerythrin and nitrogenase. J. Phycol. 42: 453-463

Furnes H., Banerjee N. R., Muehlenbachs K., Staudigel H., de Wit M. (2004) Early life recorded in Archean pillow lavas. Science 304: $578-581$

Furuya K., Saito H., Sriwoon R., Omura T., Furio E. E., Borja V. M., Lirdwitayaprasit T. (2006) Vegetative growth of Noctiluca scintillans containing the endosymbiont Pedinomonas noctilucae. Afr. J. Mar. Sci. 28: 305-308

Gast R. J., Caron D. A. (2001) Photosymbiotic associations in planktonic foraminifera and radiolaria. Hydrobiologia 461: 1-7

Gast R. J., Sanders R. W., Caron D. A. (2009) Ecological strategies of protists and their symbiotic relationships with prokaryotic microbes. Trends Microbiol. 17: 563-569

Gastrich M., Anderson O. R. (2002) Experimentally-induced association between two protists: Physarum polycephalum (Mycetozoa) and Chlorella pyrenoidosa (Chlorophyceae). Symbiosis 33: $175-190$

Gomes H. D. R., Goes J. I., Matondkar S. G. P., Parab S. G., Al-Azri A. R. N., Thoppil P. G. (2008) Blooms of Noctiluca miliaris in the Arabian Sea - An in situ and satellite study. Deep Sea Res. Part I Oceanogr. Res. Papers 55: 751-765.

Gordon N., Angel D. L., Neori A., Kress N., Kimor B. (1994) Heterotrophic dinoflagellates with symbiotic cyanobacteria and nitrogen limitation in the Gulf of Aqaba. Mar. Ecol. Prog. Ser. 107: $83-88$

Hansen P. J., Miranda L., Azanza R. (2004) Green Noctiluca scintillans: a dinoflagellate with its own greenhouse. Mar. Ecol. Prog. Ser. 275: 79-87

Hemleben C., Spindler M., Anderson O. R. (1989) Modern Planktonic Foraminifera. Springer-Verlag, Heidelberg

Jeon K. W. (1995) Bacterial symbiosis in amoebae. Trends Cell Biol. 5: 137-140

Johnson M. D., Tengs T., Oldach D., Stoecker D. K. (2006) Sequestration, performance, and functional control of cryptophyte plastids in the ciliate Myrionecta rubra (Ciliophora). J. Phycol. 42: 1235-1246

Kirchner M., Sahling G., Schuett C., Doepke H., Uhlig G. (1999) Intracellular bacteria in the red tide-forming heterotrophic dinoflagellate Noctiluca scintillans. Erg. Limnol. 54: 297-310

Kimor B., Gordon N., Neori A. (1992) Symbiotic associations among the microplankton in oligotrophic marine environments, with special reference to the Gulf of Aqaba, Red Sea. J. Plankton Res. 14: 1217-1231

Kodama Y., Fujishima M. (2009) Infection of Paramecium bursaria by symbiotic Chlorella species. In: Endosymbionts in Paramecium, (Ed. M. Fujishima). Springer-Verlag, Berlin Heidelberg, pp. 31-55

Kodama Y., Fujishima M. (2010) Induction of secondary symbiosis between the ciliate Paramecium and the green alga Chlorella. In: Current Research, Technology and Education Topics in Ap- 
plied Microbiology and Microbial Biotechnology, Microbiology Series No. 2, (Ed. A. Méndez-Vilas). Formatex, Badajoz, Spain, pp. 95-102

Lindholm T., Mork A-C. (1989) Symbiotic algae and plastids in planktonic ciliates. Mem. Soc. Faun. Flor. Fennica 65: 17-22

Madhu N. V., Jyothibabu R., Mahjeswaran P. A., Jayaraj K. A., Achuthankutty C. T. (2012) Enhanced chlorophyll a and primary production in the northern Arabian Sea during the spring intermonsoon due to green Noctiluca scintillans bloom. Mar. Biol. Res. 8: $182-188$

McManus G. B., Schoener D. M., Haberlandt K. (2012) Chloroplast symbiosis in a marine ciliate: ecophysiology and the risks of rewards of hosting foreign organelles. Front. Microbiol. 4 Sept. 2012, doi: 10.3389/fmicb.2012.00321

Mereschkowski C. (1905) Über Natur und Ursprung der Chromatophoren im Pflanzenreiche. Biol. Centralbl. 25: 593-604

Montagnes D. J. S., Lynn D. H., Roff J. C., Taylor W. D. (1988) The annual cycle of heterotrophic planktonic ciliates in the waters surrounding the Isles of Shoals, Gulf of Maine: an assessment of their trophic role. Mar. Biol. 99: 21-30

Moran D. M., Anderson O. R., Dennett M. R., Caron D. A., Gast R. J. (2007) A description of seven Antarctic marine gymnamoebae including a new subspecies and a new genus: Neoparamoeba aestuarina antarctica $\mathrm{n}$. subsp., Platyamoeba oblongota n. sp., Platyamoeba contorta $\mathrm{n}$. sp. and Vermistella antarctica $\mathrm{n}$. gen. n. sp. J. Eukaryot. Microbiol. 54: 169-183

Nakajima T., Sano A., Matsuoka H. (2009) Auto-/heterotrophic endosymbiosis evolves in a mature stage of ecosystem development in a microcosm composed of an alga, a bacterium and a ciliate. BioSystems 96: 127-135

Ota T., Taniguchi A. (2003) Standing crop of planktonic ciliates in the East China Sea and their potential grazing impact and contribution to nutrient regeneration. Deep Sea Res. Part II Top. Stud. Oceanogr. 50: 423-442

Page F. C. (1988) A New Key to Freshwater and Soil Gymnamoebae. Ambelside, Cumbria, U.K., Freshwater Biological Association
Perez M. T., Dolan J. R., Fukai E. (1997) Planktonic oligotrich ciliates in the NW Mediterranean: growth rates and consumption by copepods. Mar. Ecol. Prog. Ser. 155: 89-101

Reisser W. (1992) Endosymbiotic associations of algae with freshwater protozoa and invertebrates. In: Algae and symbioses: plants, animals, fungi, viruses, interactions explored, Vol. 1.1, (Ed. W. Reisser). Biopress, Bristol, pp. 1-19

Sagan L. (1967). On the origin of mitosing cells. J. Theor. Bio. 14: 255-274

Seibold A., Wichels A., Schütt C. (2001) Diversity of endocytic bacteria in the dinoflagellate Noctiluca scintillans. Aquat. Microb. Ecol. 25: 229-235

Soldo A. T., Brickson S. A., Vazquez D. (1992) The molecular biology of a bacterial endosymbiont. J. Protozool. 39: 196-198

Stoecker D. K., Putt M., Davis L. H., Michaels A. E. (1991) Photosynthesis in Mesodinium rubrum: species-specific measurements and comparison to community rates. Mar. Ecol. Prog. Ser. 73: 245-251

Stoecker D. K., Silver M. W., Michaels A. E., Davis L. H. (1988) Obligate mixotrophy in Laboea strobila, a ciliate which retains chloroplasts. Mar. Biol. 99: 415-424

Stoecker D. K., Johnson, M. D., de Vargas C., Not F. (2009) Acquired phototrophy in aquatic protists. Aquat. Microb. Ecol. 57: 279-310

Strom S. L. (2008) Microbial ecology of ocean biogeochemistry: A community perspective. Science 320: 1043-1045

Sweeney B. M. (1978) Ultrastructure of Noctiluca miliaris (Pyrrophyta) with green flagellate symbionts. J. Phycol. 14: 116$-120$

Yuasa T., Horiguchi T., Mayama S., Matsuoka A., Takahashi O. (2012) Ultrastructural and molecular characterization of symbionts in Dictyocoryne profunda (polycystine radiolarian). Symbiosis 57: 51-55

Received on $31^{\text {st }}$ October 2012; revised on $12^{\text {th }}$ January, 2013; accepted on $17^{\text {th }}$ January, 2013 